\title{
The impact of collaborative strategies on disaster risk reduction in Zimbabwe dairy supply chains in 2016
}

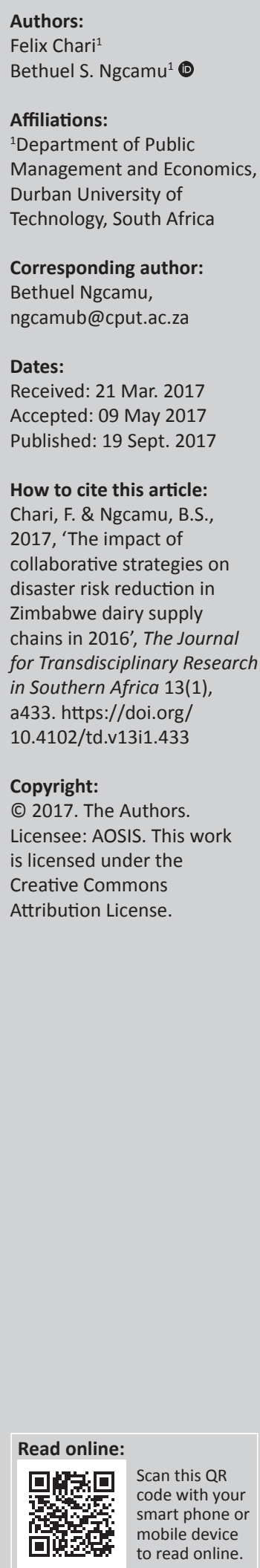

\begin{abstract}
Disasters are on the increase globally with accompanying devastating effects on dairy supply chains. The devastating effects, caused by disasters on economies in various countries such as United States of America, Japan, Kenya, Uganda, Mozambique and Zimbabwe call for urgent sustainable mitigating measures in disaster risk reduction. These countries have experienced notable natural and man-made disasters in the past. The disasters negatively impacted the economies of both developed and developing countries, causing misery to people as hunger and poverty drastically increased. Zimbabwe's dairy industry was not spared from these devastating effects as it was vulnerable to disasters such as droughts and cyclones. Disasters adversely affected supply chains in the country as evidenced by the closure of some dairy firms between the years 2000 and 2014. This article is set against the backdrop of declining output across all agricultural sectors in Zimbabwe, evident particularly in the dairy farming sector which has witnessed inadequate supply of raw milk and dairy products by local producers. The article assesses the impact of dairy organisations' partnerships with government departments and non-governmental organisations in reducing disaster risks on the dairy supply chain cost efficiency. It also aims to show how partnerships can reduce disaster risks and weighs the benefits of reduced supply chain costs in improving the affordability of milk and milk products to the general public. The study employs a mixed-methods approach comprising structured questionnaires, administered to a sample of 92 respondents out of a randomly sampled population of 122 participants from dairy farming clusters across the country, with an $85 \%$ response rate. Key informants in the form of 18 dairy officers were purposively sampled for interviews throughout the dairy farming regions. The research findings will help government in the formulation of public policies for the dairy sector network in reducing disaster risks.
\end{abstract}

\section{Introduction}

The world faces new and emerging hazards that multiply disaster risks (Ozturk \& Cherix 2013; United Nations secretariat of the International Strategy for Disaster Reduction [UNISDR] 2011). According to Ozturk and Cherix (2013), when a disaster hits, disruption that results ripples through national, regional and global supply chains, causing losses in related industries. A supply chain is a network of organisations that work together and coordinate their actions to deliver or move a product or service from supplier to customer (Subbaiah, Rao \& Babu 2009). Because of the inter-linkage of world economies, through global supply chains, nations are sensitive to disasters regardless of geographical locations (Reddy, Singh \& Anbumozhi 2016).

Globally, supply chains have been disrupted by disasters that occurred in the United States of America and Japan (Asian Development Bank [ADB] \& Asian Development Bank Institute [ADBI] 2013; Silva \& Reddy 2011). In the United States of America, about 73\% of companies experienced disruption in their supply chains network at least once in five years, with natural disasters being the most frequent cause of these disruptions (Silva \& Reddy 2011). The year 2011 witnessed the Great East Japan Earthquake and Thai floods that caused disruption to production networks and supply chains that extended to other countries in the Asian region because of the interdependencies of regional and world economies (ADB \& ADBI 2013). The tsunami that accompanied the earthquake displaced about 350000 people with most of them suffering psychological distress (Goodwin et al. 2015). The tsunami and earthquake also resulted in seafood prices rising by $6 \%$. The financial implications of these disasters were estimated at $\$ 2.2$ billion and $\$ 235$ billion for the Thai floods and the Great East Japan Earthquake, respectively (ADB \& ADBI 2013). Cost effective ways of alleviating poverty, increasing productivity and generating economic growth need to be put in place.

The 2016 El Nino weather pattern adversely affected agricultural supply chains in sub-Saharan Africa, with South Africa's production of white corn falling by 31\%, leading to food insecurity in 
the country (BizCommmunity 2016). In the same manner, an industrial action by 5000 workers at Mombasa Port in Kenya in 2015 disrupted multiple industries in the country and subsequently in neighbouring countries such as the Democratic Republic of Congo and Somalia (DHL 2016). Armed conflicts are also a significant source of food insecurity, for they disrupt both production and distribution networks as people get displaced (Hendrix \& Brinkman 2013). In Darfur, the Sudan armed conflicts brought a lot of negative effects that included reduced food crops production, destroyed educational and health infrastructure, and reduced and terminated employment. This consequently highlights the need for, and significance of, disaster risk reduction strategies across global supply chains. Hunger and food insecurity have caught the attention of the international community. About 780 million people in developing countries are undernourished mainly because of low agricultural productivity, lack of nutritious food and climate change that has increased droughts and flooding (FAO 2002).

Zimbabwe has also experienced an increase in natural and human disasters such as disease outbreaks, floods, droughts, veld fires, storms, road traffic accidents and army worm invasions affecting $6.8 \%$ of its yearly population (Betera 2011; Bongo et al. 2013; Kellett \& Spark 2012). A report by Government of Zimbabwe and United Nations (2012) suggests that related disasters are going to increase in the country. Disasters negatively impact agriculture, one of the driving forces of economies in developing countries, where human misery has drastically increased (FAO 2002). The dairy industry struggles to recover from the devastating impact of droughts, land reform programme and economic turmoil. Diets in developing regions of the world are deficient in quantity and quality terms, exposing people to hunger and malnutrition (Otte et al. 2012). Increasing the availability of animal-source foods (ASFs) such as milk, meat and eggs for poor populations could significantly reduce the burden of low nutrition levels.

Zimbabwe experienced severe droughts in the years 1991, 1992, 1995, 2008 and 2016 which had both direct and indirect consequences on the economy. Consecutive droughts exacerbated poverty, high food insecurity, hunger and disease. (Maphosa 1994; Mavhura, Manatsa \& Mushore 2015). The perennial droughts Zimbabwe experienced had severe effects on the dairy farming industry because it thrives in favourable rainfall conditions (Masama 2014). Pursuant to the droughts, tens of thousands of cattle succumbed to drought related deaths (SADC Agromet 2016). Livestock have an important contribution to poverty alleviation, economic growth and raising nutrition levels in developing countries where the demand for livestock products has increased rapidly (Otte et al. 2012). Disasters, however, were responsible for disrupting the supply chains network in the country, resulting in a decline in dairy industry production and the subsequent collapse of related firms (Commercial Farmers' Union [CFU] 2010). Poor performance across the Zimbabwe dairy sector has been evidenced by a sharp decline in the production of milk from an annual production of 187.05 million litres in year 2000 to 71 million litres in 2015 (CFU 2016). Consequently, there was inadequate supply of raw milk and dairy products across the country, leading to an influx of imported dairy products with lengthy supply chains. As a follow up, disaster risk reduction strategies targeting dairy supply chains and milk production can be an effective technique for hunger and poverty reduction (Otte et al. 2012).

Scholarships on Zimbabwe, notably by Betera (2011) and Bongo et al. (2013), have generalised the impact of disasters on the economy of the country without giving particular attention to their effects on the dairy industry. Bongo et al. (2013) examined organisational arrangements for disaster risk reduction from a rights-based perspective. They concluded that when a rights-based thrust to disaster risk reduction is adopted, the government and civil society can build on what people already know and on communities' social and cultural strengths. Tarisayi (2014) analyses the effects of flooding on rural livelihood systems in Zimbabwe. He concludes that the floods that resulted from the excessive rains in the communal areas of Neruvanga and Nemauzhe adversely affected people's crops and livestock, social networks and other non-agricultural livelihoods. It is against this background that this article seeks to assess the impact of collaborative strategies in reducing disaster risks on dairy supply chain cost efficiency in the country.

Disaster risk reduction represents a move from a humanitarian relief approach of managing disasters to prevention of disasters through reducing vulnerability to disasters (Van Riet 2009). The dairy industry is a fundamental pillar in the agro-based economy of Zimbabwe. It provides incentives for investing in disaster risk reduction. With an average of a $7 \%$ increase in global demand for milk and milk products (More 2009), there is an increased need for researches focusing on disaster risk management and reduction in general, and in the dairy supply chain in particular. There is widespread clamour that supply chain resilience in response to disaster risks means nothing unless weighed against supply chain cost efficiency (Chopra and Sodhi 2014). Some strategies of building resilience may have exorbitant costs resulting in poor financial performance by government and private organisations. It is a concern especially in developing countries where budgets are constrained and there is heavy reliance on aid and foreign borrowing. It is against the backdrop of constrained budgets existing in developing countries that supply chains call for protection from adverse disruptions and improve supply chain cost efficiency. No single individual, company, country or region can provide total management of supply chain risks. In essence, cooperation in disaster risk reduction activities among governments, both local and national, non-governmental organisations (NGOs) and the various sectors of the economy are essential in reducing disaster risks (Guzman 2003). In Zimbabwe, some government departments are mandated by law to cooperate in disaster management. Ministry of 
Environment, Water and Climate through Environmental Management (EMA) Act 13 of 2002, The Zimbabwe National Water Act 31 of 1998 and the Zimbabwe National Water Authority (ZINWA) Act 11 of 1998 are directed to participate in disaster alleviations. In the same manner, through the Dairy Services Act, Section 19 (2001), Ministry of Agriculture has plenty of responsibilities. While Ministry of Education is touted to have a significant role in disaster risk reduction, the silence in the education curriculum is a sad story for disaster risk reduction in the country (Mudavanhu 2014). In the same manner, though NGOs have assisted dairy farmers, their bad relationship with government may compromise the success of their efforts (Brown et al. 2012). This article posits that collaborative relationships in the dairy industry are indispensable in addressing disaster risks and ensuring supply chain cost efficiency. Specifically, it discusses collaboration between government ministries and NGOs in reducing disaster risks to avoid hunger and under-nutrition. The article uses supply chain costs as a proxy of supply chain efficiency.

Given, the limited role of education in disaster issues and the hostile relationship between government and NGOs in Zimbabwe, the following hypothesis is formulated linking supply chain members' collaboration with NGOs and the Ministry of Education in disaster risk reduction with supply chain cost efficiency:

Hypothesis 1: Collaboration with NGOs and Ministry of Education has insignificant influence on dairy supply chain cost efficiency.

The following hypothesis was formulated linking collaboration with the Ministries of Agriculture and Environment in disaster risk reduction with supply chain cost efficiency:

Hypothesis 2: Collaboration with the Ministries of Agriculture and Environment has significant influence on dairy supply chain cost efficiency.

This article tests the two hypotheses using a mixed research approach that involves the use of both quantitative and qualitative research methods (Creswell 2014). The use of the mixed research method enabled the researchers to combine the best of both qualitative and quantitative methods in overcoming their weaknesses, thereby providing a better understanding of the research problem (Creswell 2014; Saldanha \& O'Brien 2014). Qualitative methods use words and narratives to add meaning to quantitative data while quantitative methods enable numbers to add precision to words and narratives (Johnson \& Onwuegbuzie 2004). The study was carried out in two phases. In the first phase, 18 semi-structured interviews were employed to elicit information from dairy authorities (dairy officers with the department of Livestock Production and Development). In the second phase, 92 structured questionnaires were administered to dairy farmers (farm owners or dairy farm managers and dairy processors) to determine the cost efficiency of collaborative strategies in addressing disaster risks. The study population was divided into five regions (clusters) of Chipinge, Mutare, Harare, Gweru and Bulawayo and the proportional random sampling technique was employed to derive research samples from the dairy clusters.

The Cronbach's alpha coefficient of 0.741 was computed. The value was above the recommended threshold value of 0.7 . Content validity of the research instrument was also done (Sekaran \& Bougie 2009). The researchers sought informed consent from participants to decide whether to partake in the study or not (Sekaran \& Bougie 2009; Walliman 2011). The information given by participants was treated as confidential to guarantee the privacy of the participants (Sekaran \& Bougie 2009). The ordinary least squares (OLS) regression analysis was done to determine the impact of individual collaborative strategies on supply chain cost efficiency. Individual collaborative strategies were regressed against supply chain cost efficiency to determine their effectiveness in the dairy industry. An index for collaborative strategies that summed the variables, NGOs and the government Ministries of Agriculture, Education and Environment was computed to determine the degree of the impact. There was no known work done on the same or similar problems in the past. This led to the development of a structured questionnaire to guide the interviews with dairy farmers and dairy officers.

\section{Global disaster risks reduction}

Collaborative efforts are essential in managing disaster risk situations (Shepard 2012). There is need for disaster risk reduction through a multisectoral approach involving the collaboration of government ministries, NGOs and private sector organisations (Government of the People's Republic of Bangladesh 2010). Observations by the United Nations (2010) in El Salvador indicated that partnership between international and national NGOs can pool donor funds more effectively than individual effort. The Indonesian government has also embraced the multi-sector, multi-level and multibased approach (United Nations 2010). The United Nations (2010) has reiterated that good coordination of all stakeholders from government to the private sector is key to reducing disaster risks. Guzman (2003) concurs, argues that with the immensity and complexity of the disaster problem, no single stakeholder can effectively address the problem alone. Collaboration strategy in disaster risk reduction is a field which is growing in importance and this article sets out to assess its impact on the supply chain.

Empirical studies by Chen, Sohal and Prajogo (2013) and Murigi (2013) recommend collaboration as a strategy to mitigate risks. Collaboration has benefits that are not achieved by non-collaborative strategies (O'Donnell 2012). It gives partner organisations increased access to a wider pool of skills, technical knowledge and experience. In addition, collaboration reduces costs through elimination of duplication and sharing of information and resources. Murigi (2013), in a study of the Brooks Dairy Limited in Kenya, 
recommends that dairy companies should widen their collaboration with the supply chain's many stakeholders such as suppliers and partners in response to changes in the supply environment. The involvement of stakeholders in strategic decision-making process ensures all-encompassing robust policies and practices that will go a long way in mitigating disaster effects in dairy farming. Chen et al. (2013) concur that supply chain collaboration is a good risk mitigation strategy. They propose collaboration with suppliers, customers and internal stakeholders as a way to mitigate risks. Cooperation among stakeholders in the same organisation and among different organisations in the supply chain saves resources and improves efficiency (The Supply Chain Council Risk Research Team [SCCRRT] 2008). In the Indian dairy industry, Mishra and Shekhar (2012) recommend that milk producers should join societies and cooperate with other stakeholders to mitigate supply chain risks. However, the impact of these partnerships differs from one country to another depending on organisational arrangements and capacities as well as the political and administrative commitments of the various governments to disaster risk reduction (UNISDR 2004). As a result, the next section outlines the collaborative relationships exhibited in Zimbabwe's dairy sector.

\section{Collaborative relationships in the dairy supply chain in Zimbabwe}

NGOs collaborate with dairy stakeholders to promote improved household incomes, employment and food security (Kagoro \& Chatiza 2012). They partnered with the Zimbabwe Association of Dairy Farmers (ZADF) and exhibited a collaborative spirit by assisting dairy farmers in cattle restocking and training them in basic animal health and artificial insemination techniques (Kagoro \& Chatiza 2012; Land O'Lakes 2014). All farmers at Milk Collection Centres (MCCs) in the Eastern Highlands of Zimbabwe restocked their cattle through a loan facility from a cattle bank scheme (Land O'Lakes 2014). Milk processors, namely Dairibord Zimbabwe, Nestle and Kefalos provide extension support services and in some instances act as loan guarantors to the dairy farmers (Kagoro \& Chatiza 2012). Furthermore, the processors are putting in place measures to mitigate the effects of droughts through heifer distribution programmes. Under the programme, Dairibord Zimbabwe imported heifers and distributed them to dairy farmers across the country to boost milk production and ensure continuity of supply across dairy supply chains networks (Dairibord Holdings Limited 2015). On the same basis, the collaborative arrangements highlighted in this article establish the cost efficiency of the strategy in reducing risks in a bid to achieve poverty reduction, economic growth, reduce inequality and the mortality rate in developing countries. Of all the supply chain risk reduction efforts, collaboration that includes partners in supply chains and government has received little attention from researchers. This has motivated a study empirically testing a collaborative framework in dairy supply chains in Zimbabwe.

\section{Legislative framework in Zimbabwe}

The Government of Zimbabwe, using the Civil Defence Act of 1982, established a national board, the Civil Protection Unit (CPU) to oversee and coordinate disaster management in the country. The 1982 legislation was abrogated by the Civil Protection Act of 1989 and later by the Civil Protection Act of 2001, Chapter 10:06 (Government of Zimbabwe 1989). The CPU coordinates government departments, private organisations and NGOs in drawing up preparedness plans (Betera 2011; Chikoto \& Sadiq 2012). However, the Civil Protection Act has been criticised for being reactive and not promoting training and research relating to disasters (Betera 2011). CPU's engagement with the Ministry of Education could have enhanced training in disaster risk reduction. Georgescu (2013) posits that new challenges posed by climate change and natural catastrophes demand responses through education. She recommends that disaster risk reduction should be incorporated into the curriculum as a cross cutting theme in a number of subjects. In the same way, Mishra and Shekhar (2012) recommend education and training to address risks in the dairy food supply chains. Zimbabwe's education system has not incorporated disaster management in curriculum of secondary schools (Mudavanhu 2014). In the absence of clear education and training policies, collaboration with the Ministry of Education is not expected to work.

The participation by NGOs is frustrated by unfriendly Zimbabwe NGO Bill (2004) as it infringes the right to freedom of association and other rights, enshrined in the Zimbabwean Constitution (International Bar Association 2004). This legislation makes NGOs' relationship with government hostile because of differences in perceptions (Brown et al. 2012). The government is sceptical of NGOs and many NGOs prefer to work alone, without partnering government, as they accuse government of putting obstacles in their way (Yagub 2014). Bongo et al. (2013) indicate that NGOs are dominant players in providing relief after a disaster has occurred and NGOs may suddenly withdraw their support.

The Zimbabwean Civil Protection Act works closely with other acts such as the EMA Act 13 of 2002, The Zimbabwe National Water Act 31 of 1998 and the ZINWA Act 11 of 1998 which governs the sustainable management of resources and environment protection in Zimbabwe (Chagutah 2010). Zimbabwe takes enforcement of its environmental laws very seriously by providing for severe criminal sanctions against violators and incorporating numerous economic incentives to encourage compliance with environmental regulations. As a result, it is mandatory for the Ministry of Environment, Water and Climate to collaborate with partners that include industrialists, mines, schools, farmers, government departments, law enforcement agencies, parastatals and traditional leaders.

Through the Dairy Services Act, Section 19 (2001), Ministry of Agriculture extension workers assist dairy farmers with technical expertise on how to run their projects viably and efficiently. There is continuous inspection of dairy parlours 
and milk processing plants by the dairy unit. Dairy service officers periodically collect milk samples from farmers to check for conformity to quality and standards set out by the Dairy Services Act (2001) in order to protect consumers from unsafe and unhygienic milk and milk products. These measures are guided by the Dairy Services Act (2001) which ensures that regulatory standards are followed. This legislation directs the Ministry of Agriculture to collaborate with dairy farmers, dairy processors and retailers.

\section{Results and discussion Demographics}

The demographic data of the respondents are discussed in terms of age, gender, educational qualification, location, role assumed and experience in the dairy industry as illustrated in Table 1.

Based on Table 1, 15\% of the total respondents to the questionnaire were female and $85 \%$ were male. Results from a research by Schaper, Lassen and Theuvsen (2009) to assess risk perception and risk management strategies by dairy farmers in Germany, the Netherlands, Ireland, Switzerland and France confirm a male dominated dairy industry with $95.7 \%$ of the interviewees being male. It can be deduced from Table 1 that the majority of the respondents (47\%) fall within 51-60 years age group. This is consistent with the fact that the Zimbabwe land reform programme, of year 2000, benefited mostly senior army and government officials (Mudimu 2003), who are veterans of the liberation struggle. Table 1 also reflects that most respondents had diplomas as their highest educational qualification as shown by a mean of 2.13. A significantly high number of dairy farmers (96\%) are literate as they have formal primary education, and are able to receive training from dairy extension officers (Stichting Nederlandse Vrijwilligers [SNV] 2013). The results displayed in Table 1 indicate that Harare, which is the capital city of Zimbabwe, has the highest number of dairy farmers (31\%). Most of the sampled dairy farmers were operating in the peri-urban area of Harare. It can then be deduced from Table 1 that a few dairy farmers are relatively experienced with only $15 \%$ having at least 16 years of experience in dairying. Most of the

TABLE 1: Demographic data 2016

\begin{tabular}{llcccc}
\hline Dummies & Variable & Mean & Min & Max & Standard deviation \\
\hline Respondents & $\begin{array}{l}\text { Gender (1 if female, } \\
\text { 0 if male) }\end{array}$ & 0.15 & 0 & 1 & 0.363 \\
& $\begin{array}{l}\text { Age (6 ascending } \\
\text { categories) }\end{array}$ & 4.96 & 3 & 6 & 0.946 \\
& $\begin{array}{l}\text { Level of education (4 } \\
\text { ascending categories) }\end{array}$ & 2.13 & 1 & 4 & 0.801 \\
Region & Chipinge & 0.13 & 0 & 1 & 0.336 \\
dummies: & Gweru & 0.23 & 0 & 1 & 0.424 \\
& Harare & 0.31 & 0 & 1 & 0.465 \\
& Bulawayo & 0.21 & 0 & 1 & 0.406 \\
& Mutare & 0.13 & 0 & 1 & 0.336 \\
Experience & 0-5 years & 0.09 & 0 & 1 & 0.288 \\
& 6-10 years & 0.47 & 0 & 1 & 0.503 \\
& 11-15 years & 0.28 & 0 & 1 & 0.453 \\
& 16 years and above & 0.15 & 0 & 1 & 0.363 \\
\hline
\end{tabular}

experienced white commercial farmers were displaced during the land reform programme (Zimbabwe Human Rights NGOs Forum 2010).

Ordinary Least Squares (OLS) regression in statistical package, STATA Version (13), was computed to test hypotheses. The regression analyses are repeated using Tobit model to test for the robustness of the models. The statistical computations held the control variables, such as gender, education, experience and the regions (Chipinge, Mutare, Harare, Gweru and Bulawayo) constant to isolate the role of collaborative variables on supply chain cost efficiency. Results of the OLS regression analysis and the Tobit model show the impact of collaborative strategies on dairy supply chain efficiency and are presented in Tables 2-6. Comparing the OLS regression and Tobit models, it can be seen that the results are fairly comparable.

\section{Impact of collaboration with non-governmental organisations on supply chain costs}

The findings of this study presented in Table 2 reveal a negative relationship between NGOs and supply chain cost efficiency as evidenced by a beta value of -0.106 . However, the impact of collaboration with NGOs on dairy supply chain cost efficiency is insignificant implying that increased collaboration by NGOs would not improve dairy supply chain efficiency. Interviewees voiced the same weak association between the government and NGOs because of scepticism and lack of trust. Partnerships with NGOs were short term and had no sustainable impact. This finding, therefore, supports Hypothesis 1 of this study, which notes that collaboration with NGOs has insignificant influence on

TABLE 2: Ordinary least squares and Tobit estimates: Impact of collaboration with non-governmental organisations on supply chain costs 2016.

\begin{tabular}{lcc}
\hline Variables & $\begin{array}{c}\text { OLS results (1) } \\
\text { Supply chain costs }\end{array}$ & $\begin{array}{c}\text { Tobit results (2) } \\
\text { Supply chain costs }\end{array}$ \\
\hline NGOs & -0.106 & -0.0769 \\
Gender & $(0.153)$ & $(0.156)$ \\
Age & -0.115 & -0.0619 \\
& $(0.372)$ & $(0.390)$ \\
Level of education & 0.0243 & 0.00522 \\
& $(0.123)$ & $(0.124)$ \\
Experience & -0.162 & -0.155 \\
& $(0.162)$ & $(0.162)$ \\
Chipinge & 0.0508 & 0.0479 \\
& $(0.154)$ & $(0.153)$ \\
Gweru & 0.310 & 0.393 \\
& $(0.454)$ & $(0.467)$ \\
Harare & -0.313 & -0.247 \\
& $(0.419)$ & $(0.450)$ \\
Bulawayo & 0.00124 & 0.0130 \\
Constant & $(0.439)$ & $(0.465)$ \\
\hline Observations & -0.227 & -0.129 \\
\hline & $(0.487)$ & $(0.513)$ \\
\hline & $3.060 \S$ & $2.902 \S$ \\
& $(0.853)$ & $(0.886)$ \\
\hline & 79 & 79 \\
\hline & 0.066 & -0.0769 \\
\hline
\end{tabular}

$\mathrm{NGO}$, non-governmental organisations; OLS, ordinary least squares.

Robust standard errors in parentheses.

$\S$, Significance level is $0.01 ; \ddagger$, Significance level is 0.05 ; $\uparrow$, Significance level is 0.1 . 
dairy supply chain cost efficiency. The research result concurs with the findings by Brown et al. (2012) which indicate that the functionality of NGOs in Zimbabwe is stifled by unfriendly government policies. Collaboration among the government, the private sector and NGOs requires that the government provides an enabling environment (Forbes 2010) to have a successful private-public partnership.

\section{Impact of collaboration with Education Ministry on supply chain costs}

Table 3 illustrates the results of collaboration with the Ministry of Education on supply chain costs efficiency. No statistically significant linear dependence of supply chain costs on education was detected with an OLS beta coefficient value of -0.0227 . Sensitivity test results of the Tobit model also show no significant impact with a coefficient value of -0.00120 . Interviews with dairy officers blamed the existing school and college curricula in Zimbabwe for not incorporating extensive and relevant content on disaster risk reduction. They confirmed that the Ministry of Primary and Secondary Education has only introduced disaster management now, as a cross cutting theme in the new curriculum which is due to be introduced in 2017. Findings from interviews support Hypothesis 1 of this study which notes that collaboration with Education has insignificant influence on the dairy supply chain cost efficiency. These findings concur with Mudavanhu's (2014) conclusion that the education system in Zimbabwe has not incorporated disaster management in curriculum of secondary schools and for this reason schools could not be the focus for disaster risk reduction.

TABLE 3: Ordinary least squares and Tobit estimates: Impact of collaboration with Education Ministry on supply chain costs: 2016.

\begin{tabular}{lcc}
\hline Variables & $\begin{array}{c}\text { OLS results (1) } \\
\text { Supply chain costs }\end{array}$ & $\begin{array}{c}\text { Tobit results (2) } \\
\text { Supply chain costs }\end{array}$ \\
\hline Education & -0.0227 & -0.00120 \\
Gender & $(0.167)$ & $(0.168)$ \\
Age & -0.0694 & -0.0283 \\
& $(0.371)$ & $(0.388)$ \\
Level of education & 0.00935 & -0.00431 \\
Experience & $(0.125)$ & $(0.125)$ \\
Chipinge & -0.180 & -0.166 \\
& $(0.165)$ & $(0.167)$ \\
Gweru & 0.0553 & 0.0476 \\
& $(0.157)$ & $(0.158)$ \\
Harare & 0.333 & 0.412 \\
& $(0.455)$ & $(0.466)$ \\
Bulawayo & -0.285 & -0.228 \\
& $(0.418)$ & $(0.450)$ \\
Constant & 0.00468 & 0.0164 \\
Observations & $(0.437)$ & $(0.464)$ \\
\hline
\end{tabular}

OLS, ordinary least squares.

Robust standard errors in parentheses.

$\S$, Significance level is $0.01 ; \neq$, Significance level is 0.05 ; $\uparrow$, Significance level is 0.1 .

\section{Impact of collaboration with Agriculture Ministry on supply chain costs}

Results presented in Table 4 show that collaboration with the Ministry of Agriculture (with a beta coefficient of -0.685) has a significant impact on supply chain cost efficiency. The results imply that increased collaborative efforts with the Ministry of Agriculture led to a reduction in dairy supply chain cost efficiency, implying a reduction in the cost of supplying milk and milk products. The Tobit model results confirm that the results are showing a robust model. Interviews conducted with dairy officers confirmed significant influence of collaboration with the Ministry of Agriculture on dairy supply chain cost efficiency. The dairy and veterinary services in the ministry conducted training programmes in clean milk production to prevent milk contamination. This finding, therefore, supports Hypothesis 2 which notes that collaboration with the Ministry of Agriculture has significant influence on dairy supply chain cost efficiency. These results are consistent with the objectives of Land O'Lakes (2014) partnership with ZADF and the Ministry of Agriculture to train dairy farmers in basic animal health. The Dairy Services Act of 2001 makes it mandatory for the Ministry of Agriculture to collaborate in dairy supply chains with stakeholders who include dairy farmers, milk processors and retailers to ensure that they meet requirements for milk quality control.

\section{Impact of collaboration with Ministry of Environment, Water and Climate on supply chain costs}

The OLS regression test was also done to examine the significance of collaborative relationships with the Ministry

TABLE 4: Ordinary least squares and Tobit estimates: Impact of collaboration with Agricultural Ministry on supply chain costs: 2016.

\begin{tabular}{lcc}
\hline Variables & $\begin{array}{c}\text { OLS results (1) } \\
\text { Supply chain costs }\end{array}$ & $\begin{array}{c}\text { Tobit results (2) } \\
\text { Supply chain costs }\end{array}$ \\
\hline Agriculture & $-0.685 \ddagger$ & $-0.737 \ddagger$ \\
Gender & $(0.276)$ & $(0.298)$ \\
Age & -0.172 & -0.138 \\
& $(0.375)$ & $(0.388)$ \\
Level of education & -0.0129 & -0.0305 \\
& $(0.114)$ & $(0.114)$ \\
Experience & -0.198 & -0.189 \\
Chipinge & $(0.166)$ & $(0.167)$ \\
& 0.0905 & 0.0879 \\
Gweru & $(0.147)$ & $(0.147)$ \\
& 0.370 & 0.446 \\
Harare & $(0.438)$ & $(0.451)$ \\
& -0.263 & -0.203 \\
Bulawayo & $(0.387)$ & $(0.418)$ \\
Constant & 0.160 & 0.178 \\
Observations & $(0.417)$ & $(0.442)$ \\
\hline & -0.0548 & 0.00693 \\
& $(0.412)$ & $(0.440)$ \\
\hline Squared & $5.581 \S$ & $5.759 \S$ \\
& $(1.405)$ & $(1.504)$ \\
\hline & 79 & $-0.737 \ddagger$ \\
\hline
\end{tabular}

OLS, ordinary least squares.

Robust standard errors in parentheses.

$\S$, Significance level is $0.01 ; \ddagger$, Significance level is 0.05 ; $\uparrow$, Significance level is 0.1 . 
TABLE 5: Ordinary least squares and Tobit estimates: Impact of collaboration with the Ministry of Environment on supply chain costs: 2016

\begin{tabular}{|c|c|c|}
\hline Variables & $\begin{array}{l}\text { OLS results (1) } \\
\text { Supply chain costs }\end{array}$ & $\begin{array}{l}\text { Tobit results (2) } \\
\text { Supply chain costs }\end{array}$ \\
\hline \multirow[t]{2}{*}{ Environment } & $-0.478 \div$ & $-0.526 t$ \\
\hline & $(0.239)$ & $(0.260)$ \\
\hline \multirow[t]{2}{*}{ Gender } & -0.0646 & -0.0176 \\
\hline & $(0.353)$ & $(0.368)$ \\
\hline \multirow[t]{2}{*}{ Age } & -0.00138 & -0.0189 \\
\hline & $(0.124)$ & $(0.124)$ \\
\hline \multirow[t]{2}{*}{ Level of education } & -0.167 & -0.155 \\
\hline & $(0.161)$ & $(0.162)$ \\
\hline \multirow[t]{2}{*}{ Experience } & 0.0230 & 0.0175 \\
\hline & (0.148) & (0.149) \\
\hline \multirow[t]{2}{*}{ Chipinge } & 0.439 & 0.524 \\
\hline & $(0.434)$ & $(0.448)$ \\
\hline \multirow[t]{2}{*}{ Gweru } & -0.207 & -0.140 \\
\hline & $(0.396)$ & $(0.428)$ \\
\hline \multirow[t]{2}{*}{ Harare } & 0.0780 & 0.0892 \\
\hline & $(0.407)$ & $(0.434)$ \\
\hline \multirow[t]{2}{*}{ Bulawayo } & -0.0252 & 0.0440 \\
\hline & $(0.417)$ & $(0.445)$ \\
\hline \multirow[t]{2}{*}{ Constant } & $4.702 \S$ & $4.852 \S$ \\
\hline & $(1.106)$ & $(1.190)$ \\
\hline Observations & 79 & 79 \\
\hline$R$-squared & 0.104 & $-0.526 t$ \\
\hline
\end{tabular}

OLS, ordinary least squares.

Robust standard errors in parentheses.

$\S$, Significance level is $0.01 ; \star$, Significance level is 0.05 ; $\dagger$, Significance level is 0.1 .

of Environment, Water and Climate. Results in Table 5 show a beta coefficient value of $-0.478+$ implying that increased collaborative efforts with the Ministry of Environment, Water and Climate could lead to reduced dairy supply chain costs by reducing environmental risks and litigation costs. The Tobit model in the table confirms the same relationship and a similar impact on the supply chain cost efficiency. The results from interviews similarly show that awareness programmes on veld fires were conducted regularly to reduce the depletion of pastures. This finding, therefore, supports Hypothesis 2, which says that collaboration with the Ministry of Environment, Water and Climate has a significant influence on dairy supply chain cost efficiency. The finding is consistent with the expectations of Ministry of Environment, Water and Climate Zimbabwe Environmental to achieve cost efficiency in their endeavour to sustainably manage resources and protect the environment (Chagutah 2010).

\section{Impact of combined collaborative strategies on supply chain costs}

The results in Table 6 and interview results suggest that in the full model including all the variables collaborative strategies have a significant impact on supply chain cost efficiency with a beta value of -0.180 . The implication is that positive collaborative efforts reduce supply chain costs. This improves the affordability of milk and milk products because lower supply chain costs imply lower prices. The sensitivity test and the Tobit model confirm the same results indicating the robustness of the models. SCCRRT (2008) concurs with these findings where it recommends cooperation among departments in the same organisation and among different organisations in the supply chain to save resources and improve efficiency.
TABLE 6: Ordinary least squares and Tobit estimates: Impact of combined collaborative strategies on supply chain costs: 2016

\begin{tabular}{|c|c|c|}
\hline Variables & $\begin{array}{c}\text { OLS results (1) } \\
\text { Supply chain costs }\end{array}$ & $\begin{array}{c}\text { Tobit results (2) } \\
\text { Supply chain costs }\end{array}$ \\
\hline \multirow[t]{2}{*}{ Collaborative strategies } & $-0.180 \S$ & $-0.175 \ddagger$ \\
\hline & $(0.0673)$ & $(0.0696)$ \\
\hline \multirow[t]{2}{*}{ Gender } & -0.187 & -0.143 \\
\hline & $(0.363)$ & $(0.378)$ \\
\hline \multirow[t]{2}{*}{ Age } & -0.0104 & -0.0255 \\
\hline & $(0.120)$ & $(0.120)$ \\
\hline \multirow[t]{2}{*}{ Level of education } & -0.162 & -0.151 \\
\hline & $(0.163)$ & $(0.164)$ \\
\hline \multirow[t]{2}{*}{ Experience } & 0.0834 & 0.0792 \\
\hline & $(0.148)$ & (0.149) \\
\hline \multirow[t]{2}{*}{ Chipinge } & 0.308 & 0.382 \\
\hline & $(0.445)$ & $(0.456)$ \\
\hline \multirow[t]{2}{*}{ Gweru } & -0.265 & -0.207 \\
\hline & $(0.400)$ & $(0.432)$ \\
\hline \multirow[t]{2}{*}{ Harare } & 0.0209 & 0.0291 \\
\hline & (0.419) & $(0.447)$ \\
\hline \multirow[t]{2}{*}{ Bulawayo } & -0.265 & -0.199 \\
\hline & $(0.425)$ & $(0.452)$ \\
\hline \multirow[t]{2}{*}{ Constant } & $6.064 \S$ & $5.934 \S$ \\
\hline & $(1.500)$ & (1.575) \\
\hline Observations & 79 & 79 \\
\hline$R$-squared & 0.111 & $-0.175 \dagger$ \\
\hline
\end{tabular}

OLS, ordinary least squares.

Robust standard errors in parentheses.

$\S$, Significance level is $0.01 ; \$$, Significance level is 0.05 ; $\uparrow$, Significance level is 0.1 .

\section{Conclusion}

The article has determined the impact of collaborative efforts on disaster risk reduction on dairy supply chain cost efficiency. It concludes that overall collaboration has significant influence on supply chain cost efficiency, if a sound legislative framework is in place. Backed by solid legislation, collaboration with the Ministries of Agriculture and Environment, Water and Climate significantly influences dairy supply chain cost efficiency. However, when collaborative efforts are analysed separately, the results of collaboration with NGOs and Ministry of Education have insignificant impact on supply chain cost efficiency largely because of the absence of relevant laws. Thus, government contribution through government departments is effective in reducing disaster risks and achieving supply chain cost efficiency if schools, colleges and universities expand their curricula to include disaster related management. The Finance Ministry may be requested to channel financial resources, to the Ministry of Education, to develop and implement disaster risk reduction curricula. An enabling environment for partnership between the government and NGOs through transparent sharing of information is important.

\section{Acknowledgements Competing interests}

The authors declare that they have no financial or personal relationships which may have inappropriately influenced them in writing this article. 


\section{Authors' contributions}

F.C. was the project leader and collected data, analysed and discussed with the literature reviewed.

B.S.N. made a conceptual framework contribution.

F.C. and B.S.N. wrote the conclusion and recommendations.

\section{References}

Asian Development Bank (ADB) \& Asian Development Bank Institute (ADBI), 2013 Disaster risk management in Asia and the Pacific: Issues paper, ADBI, Tokyo, viewed 11 September 2015, from https://www.adb.org/sites/default/files/ publication/157232/adbi-rp75.pdf

Betera, L., 2011, Overview of disaster risk management and vulnerability, Civil Protection Unit, Zimbabwe, viewed 18 September 2014, from www.itu.int/en/ Protection Unit, Zimbabwe, viewed 18 September 2014, from www.itu.int/en/ Overview $\% 20$ of $\% 20$ disaster $\% 20$ management $\% 20$ and $\%$ 20vulnerability $\% 20-\% 20$ Overview $\% 20$ of $\% 20$ disaster $\% 2$
Civil $\% 20$ Protection $\% 20$ Unit.pdf

BizCommmunity, 2016, El Niño a threat to continuity of African supply chains, viewed 10 February 2017, from http://www bizcommunity.com/Article/196/553/144508. $10 \mathrm{Fe}$

Bongo, P., Chipangura, P., Sithole, M. \& Moyo, F., 2013, 'A rights-based analysis of disaster risk reduction framework in Zimbabwe and its implications for policy disaster risk reduction framework in Zimbarice', Jamba: Journal of Disaster Risk Studies 5(2), 2-11. https://doi. and practice, Jamba: Journal
org/10.4102/jamba.v5i2.81

Brown, D., Chanakira, R., Chatiza, K., Dhliwayo, M., Dodman, D., Masiiwa, M. et al., 2012, Climate change impacts, vulnerability and adaptation in Zimbabwe, working paper No. 3, International Institute for Environment and Development, London.

Chagutah, T., 2010, Climate change vulnerability and adaptation preparedness in Zimbabwe, viewed 12 January 2017, from https://za.boell.org/sites/default/files/ downloads/HBF_web_Zim_21_2.pdf

Chen, J., Sohal, A.S. \& Prajogo, D.I., 2013, 'Supply chain operational risk mitigation A collaborative approach', International Journal of Production Research 51(7) 2186-2199. https://doi.org/10.1080/00207543.2012.727490

Chikoto, G. \& Sadiq, A., 2012, Zimbabwe's emergency management system: A promising development, research project, Milwaukee, WI, viewed 23 September 2016, from http://training.fema.gov/EMIWeb/edu/CompEmMgmtBookProject.asp

Chopra, S. \& Sodhi, M.S., 2014, 'Managing risk to avoid supply chain breakdown', MITSloan Management Review 46(1), 53-62.

Commercial Farmers' Union, 2010, Zimbabwe dairy industry seen on verge of collapse following decade of land reform, annual report, viewed 20 August 2016, from http://www.cfuzim.org/index.php/agriculture/496-zimbabwe-dairy-industryseen-on-verge-of-collapse-following-decade-of-land-reform

Commercial Farmers' Union, 2016, Commercial Farmers' Union of Zimbabwe annual congress 2016. 'Building agricultural competitiveness in Zimbabwe', viewed 15 January 2017, from http://www.cfuzim.org/ cfuzimb/images/brochure2016.pdf

Creswell, J.W., 2014, Research design: Qualitative, quantitative and mixed approaches, Sage, Los Angeles, CA.

Dairibord Holdings Limited (DHL), 2015, 2015 Dairibord annual report, viewed 12 August 2016, from http://www.dairibord.com/images/dairibord_annual_report_ 2015 final1.pdf

Dairibord Holdings Limited (DHL), 2016, A look back at 2015: The top 10 supply chain disruptions, viewed 11 February 2017, from http://www.delivered.dhl.com/en/ articles/2015/11/a-look-back-at-2015-the-top-10-supply-chain-disruptions.html

FAO, 2002, 'Reducing poverty and hunger: The critical role of financing for food agriculture and rural development', paper prepared for the International Conference on Financing for Development Monterrey, Mexico, 18-22 March.

Forbes, M.L., 2010, Overview: Emerging issues for public private partnerships and disaster resilience in Asia Pacific, APEC Workshop, APE, Canberra, viewed 19 February 2016, from http://www.csr163asia.com/report/APECFinalOutcomes Report_201103.pdf

Georgescu, D., 2013, Zimbabwe curriculum review: Concept paper, MOESAC, Harare viewed 06 February 2017, from https://www.academia.edu/3008036/Zimbabwe Curriculum_Review_-_Concept_Paper

Goodwin, R., Takahashi, M., Sun, S. \& Ben-Ezra, M., 2015, 'Psychological distress among tsunami refugees from the Great East Japan earthquake', British Journal of Psychiatry Open 1(1), 92-97. https://doi.org/10.1192/bjpo.bp.115.000422

Government of the People's Republic of Bangladesh, 2010, National plan for disaster management, 2010-2015, Disaster Management Bureau, Disaster Management and Relief Division, Dhaka, Bangladesh.

Government of Zimbabwe, 1989, Civil Protection Act, Government Printers, Harare.

Government of Zimbabwe and United Nations, 2012, Zimbabwe national contingency plan, viewed 23 November 2014, from http://www.ifrc.org/docs/IDRL/Zimbabwe\% 20National\%20Contigency\%20Plan\%202012-2013.pdf

Guzman, E.M., 2003, Towards total disaster risk management approach, viewed 16 October 2016, from http://unpan1.un.org/intradoc/groups/public/documents/ APCITY/UNPAN009657.pdf

Hendrix, C. \& Brinkman, H.J., 2013, 'Food insecurity and conflict dynamics: Causal linkages and complex feedbacks', Stability: International Journal of Security and Development 2(2), Art. 26.
International Bar Association, 2004, An analysis of the Zimbabwean non-governmental organisations bill, 2004, viewed 28 January 2017, from https://www.lexisnexis. organisations bill, 2004, viewed 28 Januar/pris.pdf
com/presscenter/hottopics/Analysis.pdf

Johnson, R.B. \& Onwuegbuzie, A.J., 2004, Mixed methods research: A research paradigm whose time has come, American Educational Research Association, Washington, DC, pp. 20-24.

Kagoro, J.M. \& Chatiza, K., 2012, Evaluation of small holder dairy programmes in Zimbabwe, Stichting Nederlandse Vrijwilligers (SNV) report, Harare, Zimbabwe.

Kellett, J. \& Spark, D., 2012, Disaster risk reduction: Spending where it should count viewed 20 December 2015, from http://www.globalhumanitarianassistance.org/ wp-content/uploads/2012/03/GHA-Disaster-Risk-Report.pdf

Land O'Lakes, 2014, Zimbabwe: Restoring confidence in milk collection, Land O'Lakes International Development, viewed 09 January 2017, from https://www.landolakes. org/resources/success-stories/Zimbabwe-Restoring-Confifi-dence-in-Milk-Collectio

Maphosa, B., 1994, Lessons from the 1992 drought in Zimbabwe: The quest for alternative food policies, Nordic Journal of African Studies 3(1), 53-58.

Masama, E., 2014, 'Research note: Impact of climate change on livestock production in Zimbabwe', International Open and Distance Learning Journal 2(1), 47-53.

Mavhura, E., Manatsa, D. \& Mushore, T., 2015, 'Adaptation to drought in arid and semi-arid environments: Case of the Zambezi Valley, Zimbabwe', Jàmbá: Journa of Disaster Risk Studies 7(1), 144-150. https://doi.org/10.4102/jamba.v7i1.144

Mishra, P.K. \& Shekhar, B.R., 2012, 'Evaluating supply chain risk in Indian dairy industry: A case study', International Journal of Decision Sciences, Risk and Management 4(1), 77-91. https://doi.org/10.1504/IJDSRM.2012.046610

More, S.J., 2009, 'Global trends in milk quality: Implications for the Irish dairy industry', Irish Veterinary Journal 62(Supplement), 5-14. https://doi.org/10.1186/ 2046-0481-62-S4-S5

Mudavanhu, C., 2014, 'The impact of flood disasters on child education in Muzarabani District, Zimbabwe', Jàmbá: Journal of Disaster Risk Studies 6(1), 1-8. https://doi. org/10.4102/jamba.v6i1.138

Mudimu, G., 2003, Forum for food security in Southern Africa: Zimbabwe food security issues paper, Overseas Development Institute (ODI), London, viewed 24 July 2015,
from www.odi.org.uk/projects/03-food-security-forum/docs/ZimbabweCIPfinal.pdf

Murigi, J.M., 2013, 'Strategies of minimizing the effects of supply chain disruption caused by natural disasters in Kenya: A case study of Brookside Dairy Limited', Prime Journal of Business administration and Management 3(4), 971-978

O'Donnell, O., 2012, Strategic collaboration in local government: A review of internationa examples of strategic collaboration in local government, Local Government Research Series, Report No. 2, Institute of Public Administration, Dublin, Ireland

Otte, J., Costales, A., Dijkman, J., Pica-Ciamarra, U., Robinson, T., Ahuja, V. et al., 2012 Livestock sector development for poverty reduction: An economic and policy perspective Livestock's many virtues, Food and Agriculture Organization of the United Nations, Rome, viewed 18 March 2017, from http://www.fao.org/ docrep/015/i2744e/i2744e00.pdf

Ozturk, O. \& Cherix, A., 2013, Working together to reduce disaster risk, viewed 20 July 2014, from http://www.preventionweb.net/english/hyogo/gar/2013/en/bgdocs/ Final\%2OPwC\%20UNISDR\%20report.pdf

Reddy, V.R., Singh, S.K. \& Anbumozhi, V., 2016, Food supply chain disruption due to natural disasters: Entities, risks, and strategies for resilience, ERIA Discussion Paper Series, ERIA, Jakarta, Indonesia.

SADC Agromet, 2016, Food Security early warning systems update. 2015/2016 Agriculture season-January-February update, Issue no. 6, viewed 26 October
2016, from http://reliefweb.int/sites/reliefweb.int/files/resources/SADC_Agromet_ 2016, from http://reliefweb.int/sites/reliefweb.ir

Saldanha, D., \& O'Brien, S., 2014, Research methodologies in translation studies, Routledge, New York.

Schaper, C., Lassen, B. \& Theuvsen, L., 2009, 'Risk management in milk production: A study in five European countries', paper prepared for presentation at the 113th EAAE Seminar 'A resilient European food industry and food chain in a challenging world', Chania, Crete, Greece, 3-6 September, viewed 25 March 2015, from http://ageconsearch.umn.edu/bitstream/58130/2/Schaper.pdf

Sekaran, U. \& Bougie, R., 2009, Research methods for business: A skill-building approach, 4th edn., Wiley, New York.

Shepard, D., 2012, Collaborative demand and supply planning between partners: Best practices for effective planning, Supply Chain Acuity, Los Angeles, CA.

Silva, J. \& Reddy, S., 2011, 'A framework for reducing disaster risks in supply chains', International Journal of Business Research 11(4), 112.

Stichting Nederlandse Vrijwilligers (SNV), 2013, Rural agriculture revitalisation program: Dairy breeding study report, SNV, Harare, Zimbabwe.

Subbaiah, K.V., Rao, K.N. \& Babu, K.N., 2009, 'Supply chain management in a dairy industry - A case study', World Congress on Engineering 1, 595-599.

Tarisayi, K.S., 2014, 'Ramifications of flooding on livelihoods: A case of two communal areas in Chivi district in Zimbabwe', The International Journal of Humanities and Social Studies 2(2), 165-167.

The Supply Chain Council Risk Research Team (TSCCRRT), 2008, Managing risk in your organisation with the SCOR model, viewed 14 October 2016, from https://www. coursehero.com/file/14651239/downloadpdf/

UNISDR, 2004, Living with risk: A global review of disaster reduction initiatives, vol. 1 , United Nations, New York, viewed 13 June 2016, from https://www.unisdr.org/ files/657_Iwr1.pdf

UNISDR, 2011, 2011 Global assessment report on disaster risk reduction: Revealing risk, redefining development, UNISDR, Geneva, viewed 22 February 2015, from https://www.unisdr.org/we/inform/publications/19846 
United Nations, 2010, Local governments and disaster risk reduction: Good practices and lessons learned: A contribution to the 'Making Cities Resilient' Campaign, United Nations Secretariat of the International Strategy for Disaster Reduction (UNISDR), Geneva, viewed 11 May 2016, from http://unpan1.un.org/intradoc/ groups/public/documents/eropa/unpan047282.pdf

Van Riet, G., 2009, 'Disaster risk assessment in South Africa: Some current challenges', South African Review of Sociology 40(2):194-208.
Walliman, N., 2011, Research methods: The basics, 4th edn., Routledge, New York.

Yagub, I.A.A., 2014, 'Collaboration between government and non-governmental organizations in delivering curative health services in North Darfur state, Sudan. A national report', Iranian Journal of Public Health 43(5), 561-571.

Zimbabwe Human Rights NGOs Forum, 2010, Land reform and property rights in Zimbabwe, Zimbabwe Human Rights NGOs Forum, viewed 22 August 2015, from http://archive.kubatana.net/docs/hr/hrf_land_reform_property_rights_100812.pdf 